\title{
Obtaining of strontium doped fluorapatite powders
}

\author{
S.Yu.Sayenko \\ NSC "Kharkiv Institute of Physics and Technology", \\ Akademicheskaya 1 Str., 61108 Kharkiv, Ukraine
}

Received February 15, 2015

\begin{abstract}
Possibility of obtaining powders of calcium $\mathrm{Ca}_{10}\left(\mathrm{PO}_{4}\right)_{6} \mathrm{~F}_{2}$ and strontium-containing $\mathrm{Ca}_{9} \mathrm{Sr}\left(\mathrm{PO}_{4}\right)_{6} \mathrm{~F}_{2}$ fluorapatites by both solid phase reaction method with subsequent heat treatment and chemical co-precipitation method from solutions of the initial components was investigated. It was shown that the total synthesis of calcium $\mathrm{Ca}_{10}\left(\mathrm{PO}_{4}\right)_{6} \mathrm{~F}_{2}$ and strontium-containing $\mathrm{Ca}_{9} \mathrm{Sr}\left(\mathrm{PO}_{4}\right)_{6} \mathrm{~F}_{2}$ fluorapatites by solid phase method occurs at a temperature of $900^{\circ} \mathrm{C}$, and by chemical co-precipitation as a result of the reaction between initial components. Obtained nanosized powders of calcium and strontium-containing fluorapatites were produced by chemical co-precipitation method.
\end{abstract}

Keywords: radioactive wastes, immobilization, fluorapatite, synthesis, thermal stability.

Исследована возможность получения порошков кальциевого $\mathrm{Ca}_{10}\left(\mathrm{PO}_{4}\right)_{6} \mathrm{~F}_{2}$ и стронцийсодержащего фторапатита $\mathrm{Ca}_{9} \mathrm{Sr}\left(\mathrm{PO}_{4}\right)_{6} \mathrm{~F}_{2}$ двумя способами: методом твердофазных реакций с последующей термообработкой и методом химического осаждения растворов исходных компонентов. Показано, что полный синтез фторапатитов $\mathrm{Ca}_{10}\left(\mathrm{PO}_{4}\right)_{6} \mathrm{~F}_{2}$ и $\mathrm{Ca}_{9} \mathrm{Sr}\left(\mathrm{PO}_{4}\right)_{6} \mathrm{~F}_{2}$ при твердофазном способе происходит при температуре $900^{\circ} \mathrm{C}$, при химическом осаждении - непосредственно в результате реакции между исходными компонентами. Методом химического осаждения получены наноразмерные порошки кальциевого и стронций-содержащего фторапатита.

Отримання порошків фторапатиту, допірованого стронцієм. С.Ю.Саєнко.

Досліджено можливість отримання порошків кальцієвого $\mathrm{Ca}_{10}\left(\mathrm{PO}_{4}\right)_{6} \mathrm{~F}_{2}$ та стронційвміщуючого фторапатиту $\mathrm{Ca}_{9} \mathrm{Sr}\left(\mathrm{PO}_{4}\right)_{6} \mathrm{~F}_{2}$ двома способами: методом твердофазних реакцій з подальшою термообробкою і методом хімічного осадження розчинів вихідних компонентів. Показано, що повний синтез фторапатитів $\mathrm{Ca}_{10}\left(\mathrm{PO}_{4}\right)_{6} \mathrm{~F}_{2}$ та $\mathrm{Ca}_{9} \mathrm{Sr}\left(\mathrm{PO}_{4}\right)_{6} \mathrm{~F}_{2}$ при твердофазному способі відбувається при температурі $900^{\circ} \mathrm{C}$, при хімічному осадженні - безпосередньо в результаті реакції між вихідними компонентами. Методом хімічного осадження отримано нанорозмірні порошки кальцієвого та стронцій-вміщуючого фторапатиту.

\section{Introduction}

World practice of spent nuclear fuel (SNF) reprocessing provides, first of all, the extraction of uranium and plutonium, and thus the basic mass of radionuclides penetrates into the high-level wastes (HLW). HLW contain fission products, transuranium elements, components, contaminated construction elements and the remaining small fraction of unextracted uranium and plutonium. The presence in the HLW of a relatively small amount of radionuclides such as long-lived transuranic nuclides and fission products $\left({ }^{129},{ }^{99} \mathrm{Tc}\right)$ is caused an extremely long radiation hazard of HLW and the associated risks to humans and the environment. The strategy of the long-term safety of HLW management is based on the principles of multi barriers protection, ie, the system of multiple barriers, each of 
which may independently guarantee the immobilization of HLW.

Engineered barriers, such as the matrices, with incorporated radionuclides, durable corrosion-resistant containers and a layer of sorption material (bentonite), together with the natural protective barrier (geological environment) are guaranteed the safety of HLW deep geological disposal. Protective matrices for radionuclides immobilization are the main elements of any HLW isolation system. In spite of the great variety of existed protective matrices, final choice in favor of any of its types has not been made yet. One of the most promising matrices for immobilization of radionuclides is mineral-like crystalline matrix based on fluorapatite. It is known that the mineral of the apatite group - fluorapatite $\mathrm{Ca}_{10}\left(\mathrm{PO}_{4}\right)_{6} \mathrm{~F}_{2}$ has a wide spectrum of isoand hetero-valent substitutions in crystalline structure [1] and possesses a high radiation and corrosion resistance [2-4].

The present study is focused on the producing of calcium and strontium fluorapatites powders by solid phase reactions method and co-precipitation of solutions of the initial components.

\section{Experimental}

Two methods to obtain powders calcium $\mathrm{Ca}_{10}\left(\mathrm{PO}_{4}\right)_{6} \mathrm{~F}_{2}$ (FAP) and strontium-containing $\mathrm{Ca}_{9} \mathrm{Sr}\left(\mathrm{PO}_{4}\right)_{6} \mathrm{~F}_{2}$ (SFAP) fluorapatite by solid-phase synthesis and co-precipitation from solutions were realized. Synthesis of FAP and SFAP using solid phase reactions was carried out. For FAP producing the chemically pure reagents in the required stoichiometric ratio were used: calcium pyrophosphate $\mathrm{Ca}_{2} \mathrm{P}_{2} \mathrm{O}_{7}$, calcium fluoride $\mathrm{CaF}_{2}$, calcium carbonate $\mathrm{CaCO}_{3}$ and phosphoric acid $\mathrm{H}_{3} \mathrm{PO}_{4}$. The initial components are mixed in a mill in isopropyl alcohol and dried at a temperature about $100^{\circ} \mathrm{C}$ to a residual moisture content (3-5) \%. In the case of SFAP fluorapatite synthesis the strontium was added to mixture by using the strontium nitro-acid $\operatorname{Sr}\left(\mathrm{NO}_{3}\right)_{2}$ in an aqueous solution. This method provides a uniform distribution of the strontium nitroacid in the mixture [5]. Then, the needed heat treatment was carried out.

For FAP and SFAP fluorapatites produced by chemical co-precipitation a chemically pure reagents: calcium nitrate $\mathrm{Ca}\left(\mathrm{NO}_{3}\right)_{2} \cdot 4 \mathrm{H}_{2} \mathrm{O}$, disodium ammonium phosphate $\left(\mathrm{NH}_{4}\right)_{2} \mathrm{HPO}_{4}$, ammonium fluoride $\mathrm{NH}_{4} \mathrm{~F}$ and strontium nitro-acid $\mathrm{Sr}\left(\mathrm{NO}_{3}\right)_{2}$ (for

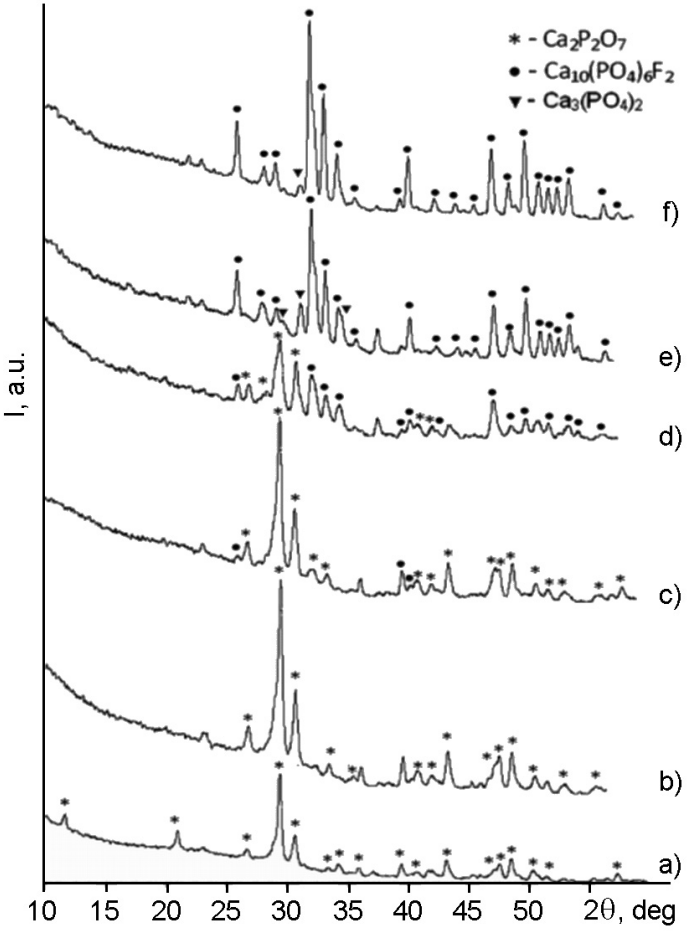

Fig. 1. Diffractograms of FAP samples sintered at different temperatures. a) initial mixture; b) after heat treatment at temperatures $500^{\circ} \mathrm{C}$; c) $600^{\circ} \mathrm{C}$; d) $700^{\circ} \mathrm{C}$; e) $900^{\circ} \mathrm{C}$; f) $1100^{\circ} \mathrm{C}$.

SFAP) were used. The process of preparation includes the following steps:

- preparing of aqueous solutions of the initial components: $\mathrm{Ca}\left(\mathrm{NO}_{3}\right)_{2} \cdot 4 \mathrm{H}_{2} \mathrm{O}$, $\mathrm{Sr}\left(\mathrm{NO}_{3}\right)_{2},\left(\mathrm{NH}_{4}\right)_{2} \mathrm{HPO}_{4}$ and $\mathrm{NH}_{4} \mathrm{~F}$;

- mixing of the initial solutions, $\mathrm{pH}=$ (9-9.5) was adjusted by adding the ammonium hydroxide $\mathrm{NH}_{4} \mathrm{OH}$;

- obtaining powders of FAP and SFAP: precipitates washing, air-drying, grinding.

The heat treatment of FAP and SFAP powders obtained by the two methods was performed in air at the temperature range (100-1200) ${ }^{\circ} \mathrm{C}$ in Nabertherm $\mathrm{GmbH}$ L5/13/B180 furnace. Differential thermal analysis and thermogravimetric analysis (DTA/TGA) was performed on a thermal analyzer SDT Q600 at the temperature range $(50-1300)^{\circ} \mathrm{C}$, with heating rate of $10^{\circ} \mathrm{C} / \mathrm{min}$. The phase analysis was carried out by X-ray diffraction (XRD) on a DRON1.5 equipment. Electron microscopic images of fluorapatite powders were made on transmission microscope TEM 123K. Infrared (IR) absorption spectra of FAP and SFAP powders were recorded by spectrometer $\mathrm{Ni}$ colet 6700 in frequency range of (400$4000) \mathrm{cm}^{-1}$. Content of calcium and phos- 


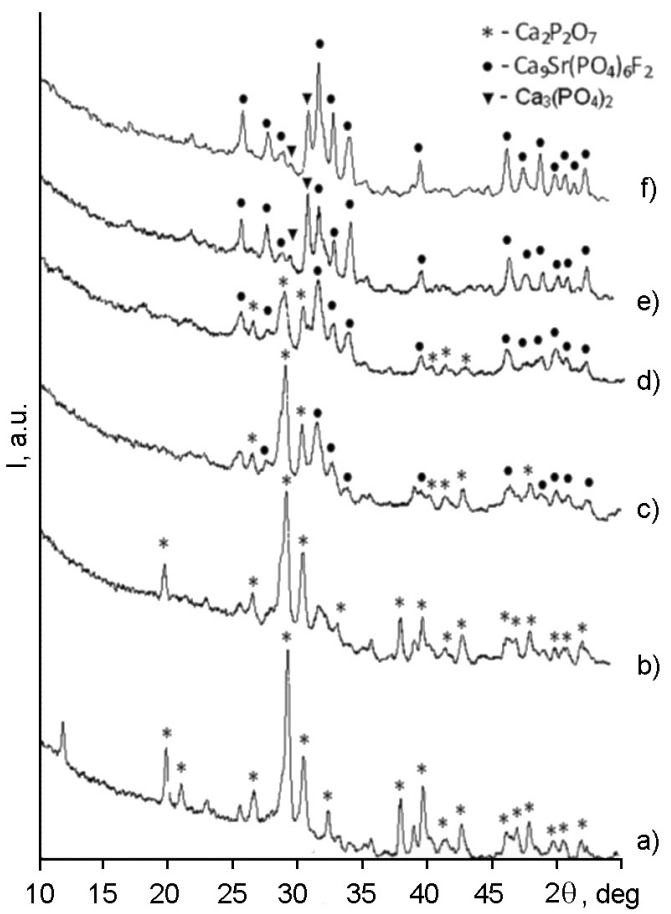

Fig. 2. Diffractograms of SFAP samples sintered at different temperatures: a) initial mixture; b) after heat treatment at temperatures $500^{\circ} \mathrm{C}$; c) $600^{\circ} \mathrm{C}$; d) $700^{\circ} \mathrm{C}$; e) $900^{\circ} \mathrm{C}$; f) $1100^{\circ} \mathrm{C}$.

phorus in the fluoroapatite samples was determined by laser mass-spectrometer of high resolution EMAL-2 with double focusing.

\section{Results and discussion}

Synthesis of FAP and SFAP by solidphase synthesis

To determine the optimum temperature of FAP and SFAP synthesis, the research of phase composition of the initial mixture after heat treatment at the temperature range $(100-1200)^{\circ} \mathrm{C}$ with steps of $100^{\circ} \mathrm{C}$ and exposure for $1 \mathrm{~h}$ by XRD analysis was carried out. Only lines of calcium pyrophosphate $\mathrm{Ca}_{2} \mathrm{P}_{2} \mathrm{O}_{7}$ (Fig. 1a) were observed in the diffractogram after mixing of the initial components. Powder mixture heating up to $500^{\circ} \mathrm{C}$ was not resulted in phase composition changes (Fig. 1b). The appearance of the first FAP lines after a heat treatment at $600^{\circ} \mathrm{C}$ was observed (Fig. 1c). At a temperature of $700^{\circ} \mathrm{C}$, the increase in the number of FAP lines, as well as reduce in the intensity of the $\mathrm{Ca}_{2} \mathrm{P}_{2} \mathrm{O}_{7}$ lines was detected (Fig. 1d). Total synthesis of FAP took place at a temperature of $900^{\circ} \mathrm{C}$ (Fig. $1 \mathrm{e})$. In addition to the lines of the synthesized FAP, lines of the three-calcium phosphate $\mathrm{Ca}_{3}\left(\mathrm{PO}_{4}\right)_{2}$ (TCP) were recorded. With

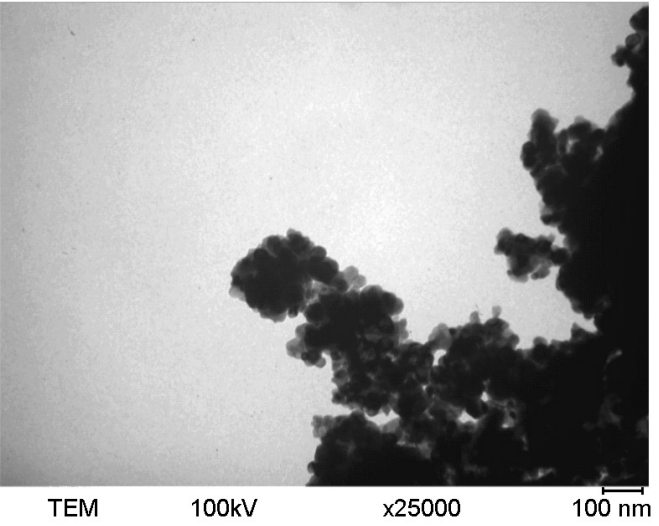

a)

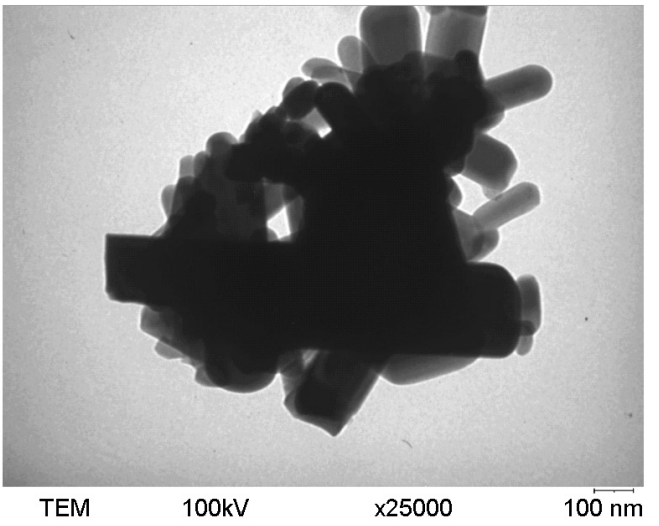

b)

Fig. 3. TEM - photographs of FAP (a) and SFAP (b) powders obtained by chemical coprecipitation.

increasing of the annealing temperature up to $1100^{\circ} \mathrm{C}$ enhanced crystallization of FAP took place with reducing the intensity and the number of TCP lines (Fig. 1f).

The start of SFAP synthesis took place at a temperature of $600^{\circ} \mathrm{C}$ (Fig. 2c). In this case, the appearance of a large number of SFAP lines was observed, in comparison with the synthesis of FAP at the same temperature. Total synthesis of SFAP was recorded at a temperature of $900^{\circ} \mathrm{C}$ (Fig. 2e). As in the case of the FAP synthesis on the diffractogram of the SFAP powder TCP lines were appeared. The appearance of a large number of TCP lines, especially in the case of the SFAP synthesis, maybe a result of some problems with the initial homogenous mixture preparing. Therefore, in order to obtain single phase of FAP and SFAP fluorapatites, the wet chemical co-precipitation method was used [6]. It is known that chemical co-precipitation method gives the possibility to obtain a final highly dispersed powder with a given chemical composition, 


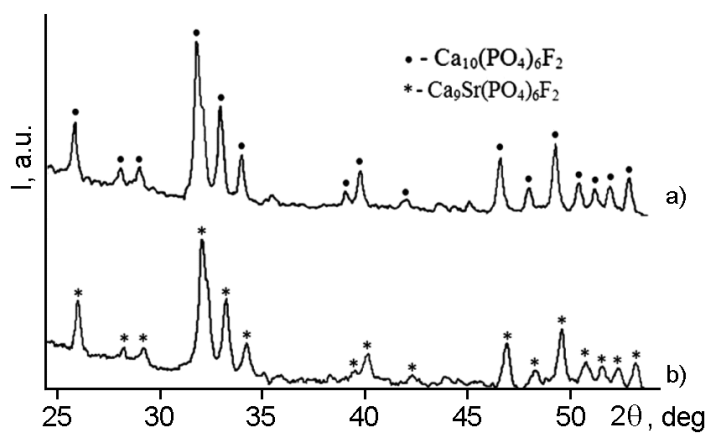

Fig. 4. Diffractograms of FAP (a) and SFAP (b) powders obtained by chemical co-precipitation.

due to a uniform distribution of elements in the co-precipitation substance.

Synthesis of FAP and SFAP by chemical co-precipitation method from solutions of the initial components

After synthesis, chemical vapor deposition and drying of FAP and SFAP powders were conducted their TEM study, XRD and DTA/TGA analyzes. As seen from the TEM - photographs, the particles are preferably FAP powders of spherical shape with radii of (20-30) nm (Fig. 3a). SFAP powder particles are characterized by three different kinds of forms (Fig. 3b): spherical (radius about $50 \mathrm{~nm})$, a smaller prismatic ( $200 \mathrm{~nm}$ height, rib $\sim 30 \mathrm{~nm}$ ) and large prismatic $(\sim 1.1 \mathrm{~nm}$ height, a rib $\sim 250 \mathrm{~nm})$. Increase the average particle size of the powder SFAP compared with FAP powder, apparently due to the effect of strontium on the formation of individual powder particles SFAP. The increase in the average particle size of the powder synthesized fluorapatite in the case of partial replacement of calcium to magnesium was also observed by the authors of article [7].

Fig. 4 presents the XRD diffractograms of FAP and SFAP powders obtained by coprecipitation. It is seen that the diffraction

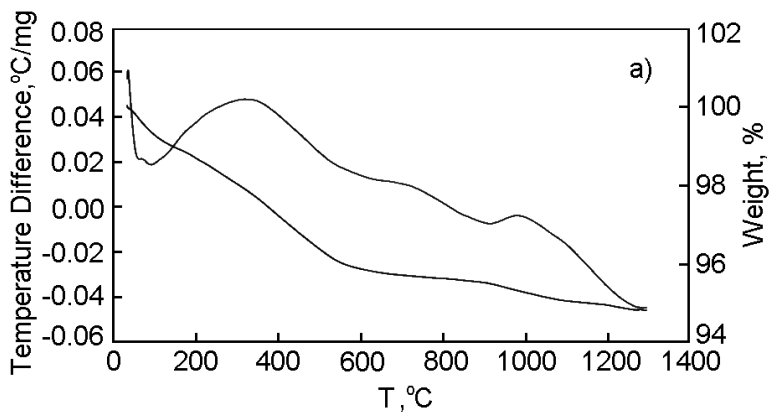

lines are presented only by one phase $\mathrm{Ca}_{10}\left(\mathrm{PO}_{4}\right)_{6} \mathrm{~F}_{2}$ (Fig. 4a) and $\mathrm{Ca}$ Sr $\left(\mathrm{PO}_{4}\right)_{6} \mathrm{~F}_{2}$ (Fig. 4b) for FAP and SFAP, respectively. In contrast to SFAP and FAP samples obtained by solid-phase synthesis (Figs. 1, 2), fluoroapatite formation by chemical co-precipitation took place directly by the reaction between the initial components.

DTA/TG analysis of FAP and SFAP powders obtained by chemical co-precipitation showed the presence of endothermic peaks at the temperature of approximately $100^{\circ} \mathrm{C}$, which corresponds to the removal of adsorbed water (Fig. 5). Removal of bound water during heating process took place up to temperatures of approximately $600^{\circ} \mathrm{C}$.

Fig. 6 shows the IR spectra of the FAP and SFAP powders prepared by chemical coprecipitation method. Spectra of FAP and SFPA powders present absorption bands of $\mathrm{PO}_{4}{ }^{3-}, \mathrm{CO}_{3}{ }^{2-}$ and $\mathrm{H}_{2} \mathrm{O}$ [8-11]. Absorption band at (1100-1030) $\mathrm{cm}^{-1}$ and (950920) $\mathrm{cm}^{-1}$, respectively, belong to the antisymmetric and symmetric vibrations of phosphate bond $\mathrm{P}-\mathrm{O}$, and the bands at 605 , 575-565 and $495-475 \mathrm{~cm}^{-1}$ — to triply degenerate deformation vibrations of O-P-O in phosphate group. The presence of ions $\mathrm{CO}_{3}{ }^{2-}$ may be caused by the absorption of atmospheric carbon dioxide in the synthesized FAP and SFAP powders [12]. FAP and SFAP powders were saturated with water during their storage. As can be seen from Fig. 6, the IR spectra of FAP and SFAP powders are similar, taking into account the small displacements of the main absorption bands.

Investigation of the thermal phase stability (formation of other phases during heating to high temperatures) of FAP and SFAP powders obtained by chemical co-precipitation in the temperature range $(100-1200)^{\circ} \mathrm{C}$ was carried out. The XRD data of heattreated FAP and SFAP powders indicate thermal decomposition at $900^{\circ} \mathrm{C}$ of synthesized fluoroapatite. The appearance of TCP

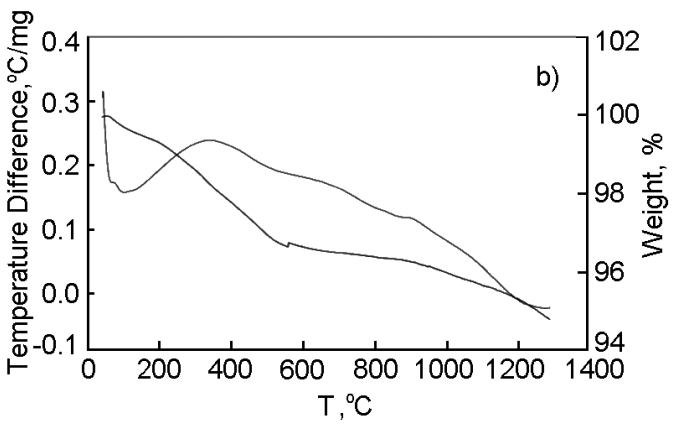

Fig. 5. DTA/TGA analysis of FAP (a) and SFAP (b) powders obtained by chemical co-precipitation. 

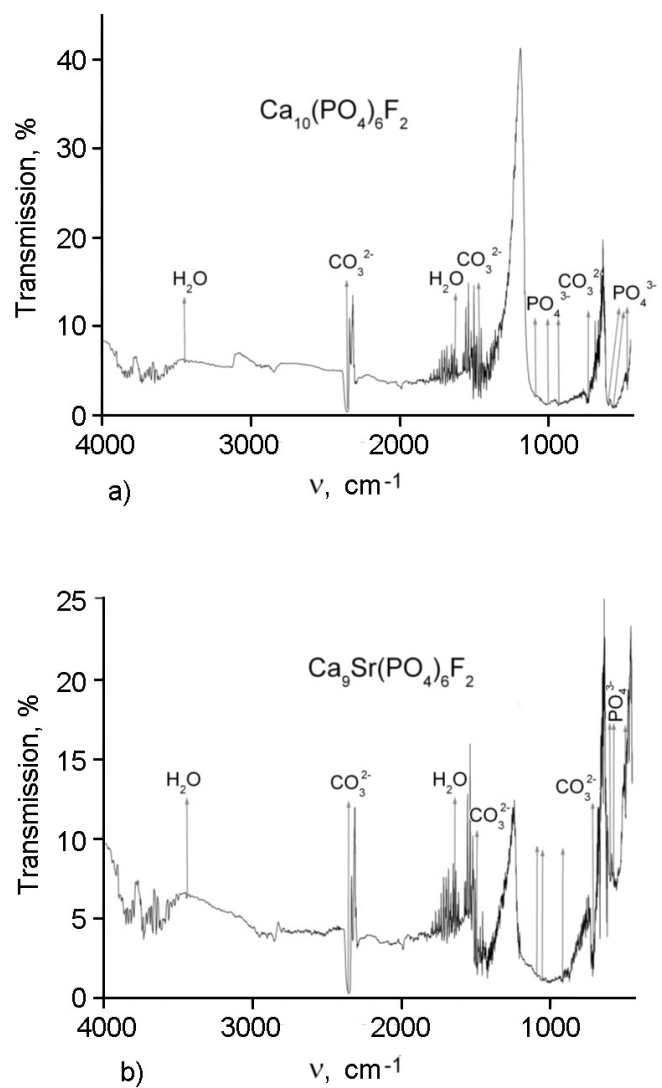

Fig. 6. IR spectra of the FAP (a) and SFAP (b) powders prepared by chemical co-precipitation method.

lines of low intensity in diffractograms was observed after heat treatment at $900^{\circ} \mathrm{C}$ of the FAP and SFAP powders (Fig. 7).

A small endothermic peak at $\sim 900^{\circ} \mathrm{C}$ for the DTA curve (Fig. 5) was recorded, probably due to the start of thermal decomposition of FAP and SFAP. After the heat treatment temperature increasing up to $1150^{\circ} \mathrm{C}$, the phase composition of FAP and SFAP was unchanged. At the same time, according to Fig. 8, the increase in the number of TCP lines in the diffractograms of SFAP in comparison with SFAP, heat treated at $900^{\circ} \mathrm{C}$ is observed. The decrease of thermal stability, presumably due to deviations from stoichiometry of obtained fluorapatite $(\mathrm{Ca} / \mathrm{P}=1.7$, whereas the theoretical ratio of $\mathrm{Ca} / \mathrm{P}$ is 1.67$)$. Increasing of the TCP phase during SFAP heat treatment above $1150^{\circ} \mathrm{C}$, probably also due to the influence of strontium ions in the fluorapatite structure having a larger ionic radius compared with calcium ions. The decrease of the thermal stability of apatite obtained by chemical co-precipitation, was previously reported [13, 14].

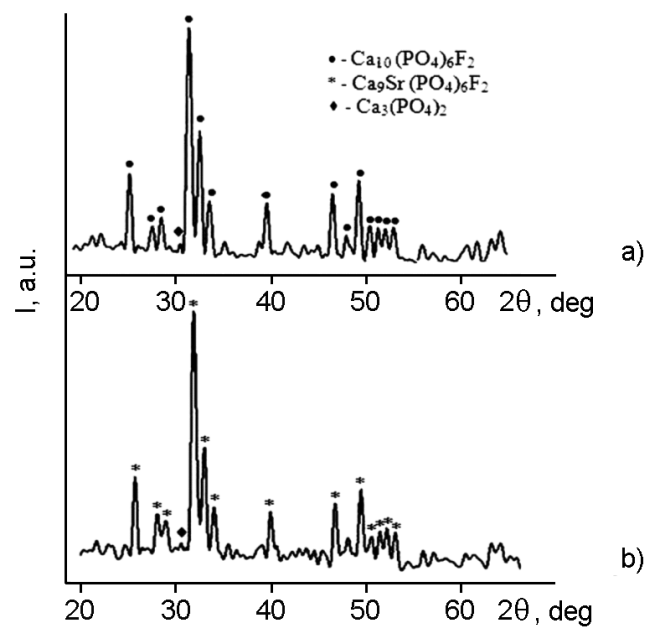

Fig. 7. Diffractograms of the FAP (a) and SFAP (b) powders after heat treatment at $900^{\circ} \mathrm{C}$ during $1 \mathrm{~h}$.

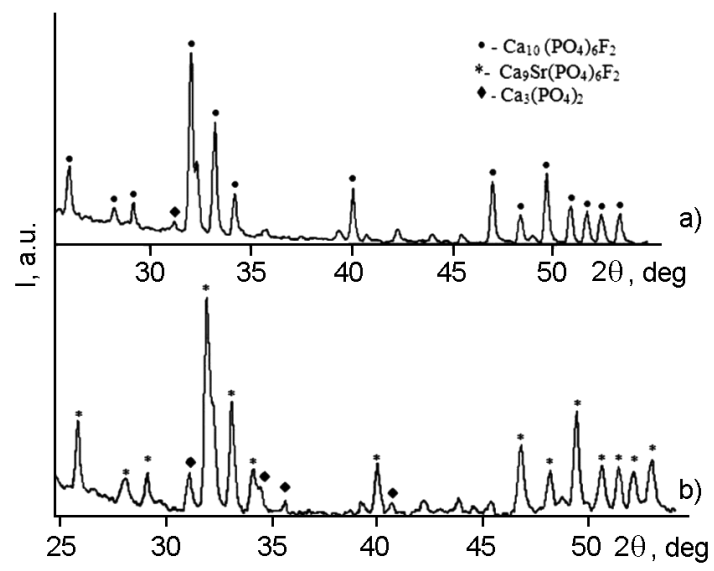

Fig. 8. Diffractograms of the FAP (a) and SFAP (b) powders after heat treatment at $1150^{\circ} \mathrm{C}$ during $1 \mathrm{~h}$.

\section{Conclusions}

The experimental investigation was carried out to study the possibility of obtaining powders of calcium $\mathrm{Ca}_{10}\left(\mathrm{PO}_{4}\right)_{6} \mathrm{~F}_{2}$ and strontium-containing $\mathrm{Ca} 9 \mathrm{Sr}\left(\mathrm{PO}_{4}\right)_{6} \mathrm{~F}_{2}$ fluorapatites by both solid phase reaction method with subsequent heat treatment and chemical co-precipitation from solutions of the initial components. It was shown that the total synthesis of calcium $\mathrm{Ca}_{10}\left(\mathrm{PO}_{4}\right)_{6} \mathrm{~F}_{2}$ and strontium-containing $\mathrm{Ca}_{9} \mathrm{Sr}\left(\mathrm{PO}_{4}\right)_{6} \mathrm{~F}_{2}$ fluorapatites by solid phase method occurs at a temperature of $900^{\circ} \mathrm{C}$. Nano-sized powres of fluorapatite of different compositions such as $\mathrm{Ca}_{10}\left(\mathrm{PO}_{4}\right)_{6} \mathrm{~F}_{2}$ and $\mathrm{Ca} \mathrm{Sr}\left(\mathrm{PO}_{4}\right)_{6} \mathrm{~F}_{2}$ were produced by chemical co-precipitation method. There was established that, in contrast to the solid-phase synthesis, the forma- 
tion of fluorapatite by the chemical co-precipitation method took place directly as a result of the reaction between the initial components of the solutions. Heat treatment of calcium and strontium fluoroapatites obtained by both solid phase synthesis and chemical co-precipitation methods at temperatures above $900^{\circ} \mathrm{C}$ leads to the formation of concomitant phase of three-calcium phosphate $\mathrm{Ca}_{3}\left(\mathrm{PO}_{4}\right)_{2}$.

\section{References}

1. J.C.Elliott, Structure and Chemistry of the Apatites and Other Calcium Phosphates, Elsevier, Amsterdam (1994).

2. N.Senamaud, D.Bernache-Assollant, J.Carpena, C.Pin, in: Mater. Res. Soc. Symp. Proc., 556, Warrendale, PA (1999).

3. J.Lian, L.M.Wang, K.Sun, R.C.Ewing, $M i-$ crosc. Res. and Techn., 72, 165 (2009)

4. J.Carpena, J.L.Lacout, Nucl.Instr. Meth. Phys. Res., B, 268, 3191 (2010).
5. V.A.Shkuropatenko, R.V.Tarasov, E.A.Pudivus et al., Probl. Atomic Sci. and Techn., 81, 98 (2012).

6. T.Kanazava, Inorganic Phosphate Materials, Naukova Dumka, Kiev (1998) [in Russian].

7. S.Nasr, K.Bouzouita, Bioinorgan. Chem. and Appl., ID 453759 (2011).

8. F.Ben Ayed, J.Bouaziz, K.Bouzouita, J.Alloys and Comp., 322, 238 (2001).

9. H.Eslami, M.Solati-Hashjin, M.Tahriri, J. Ceramic Proc. Res., 9, 224 (2008).

10. A.Guidara, K.Chaari, J.Bouaziz, Journal of Biomater. and Nanobiotechn., 2, 103 (2011).

11. S.C.Liou, S.Y.Chen, Y.Y.Lee, J.S.Bow, Biomaterials, 25, 189 (2004).

12. A.Smith, Applied IR Spectrometry, Moscow, Mir, 327 (1982).

13. R.Baraba's, A.Pop, E.Fazakas, V.Dejeu, in: Proc. of the 10th ECerS Conf., Berlin (2007), p.925.

14. Y.Chen, X.Miao, Biomaterials, 26, 1205 (2005). 